\title{
Manifestations of Moral Panics in the Sentencing of Palm Islander Lex Wotton ${ }^{\dagger}$
}

\begin{abstract}
This Comment considers the sentencing of Palm Islander man, Lex Patrick Wotton, for his involvement in the protest following the death in custody of Mulrunji. It examines the protest as a response to the police role in the death and the police mishandling of the consequent investigation. The Comment critiques the media trial that paralleled Wotton's court trial. The mainstream media, along with the Queensland Government and police union, produced a moral panic over the Palm Island protest that overshadowed the death in custody. This Comment argues that the court that sentenced Wotton appropriated the moral panic over the offence to remove the death in custody as a sentencing factor.
\end{abstract}

\section{Background to the Sentencing: Mulrunji's Death in Custody}

The death of Mulrunji was about the 230th Indigenous death in custody since the Royal Commission Into Aboriginal Deaths in Custody (RCIADIC) handed down its report in 1991 (ABS 2007:358). Not only is this figure alarming, but also were the circumstances surrounding Mulrunji's death. The lead-up and review of the death were in direct contradistinction to RCIADIC's (1991) recommendations: to refrain from arresting Indigenous people for offensive language (Recommendation 86a); that arrest should be the sanction of 'last resort' (Recommendation 87), and that a coronial inquiry and investigation into a death in custody should be conducted independently from the responsible officers (Recommendations 27, 33). Regarding the first point, Commissioner Wooten (1991) commented in the RCIADIC Report, 'it is surely time that police learnt to ignore ... simple "bad language", that is 'in general use amongst police no less than amongst other people'.

Senior Sergeant Chris Hurley arrested and detained Mulrunji for offensive language on 19 November 2004. The 36-year-old Palm Islander man had no significant criminal record and was known for his happy-go-lucky character. Forty minutes after his arrest Mulrunji was dead in the Palm Island police station. The injuries he sustained in custody were a black eye, four broken ribs, a ruptured liver - cloven in two - and a ruptured portal vein.

While the Palm Island community was mourning Mulrunji's death, public meetings were held during the week following his death. A major concern was the 'lack of any police action to bring anybody to heel concerning that death' (Levitt 2008). The investigation into the death in custody was mishandled profoundly. Mayor Erykah Kyle told one of the community meetings that the pathology report from Mulrunji's autopsy, which was sent to the Coroner, suggested that the death was an accident - Mulrunji had slipped on a step. ${ }^{1}$ For the community the official response from the Coroner's Office represented 'another example of how another grave injustice in their community was not going to be examined' (Boe 2008).

The author would like to thank sincerely Professor Phil Scraton for his feedback and insights.

It was only after an independent review of the coronial evidence and a prosecution outside the office of the Director of Public Prosecutions that the responsible officer, Senior Sergeant Hurley, was prosecuted for the death of Mulrunji. Hurley was acquitted in June 2007. 
The community was further alarmed and outraged on becoming aware that close friends of Hurley were investigating Hurley's involvement in the death of Mulrunji. These 'relationships between the investigating police officers and the police officer under investigation' ( $R v$ Wotton 2007 at [4]) sent a clear message to the community that justice over the death would not be delivered. This message was enforced when it transpired that Hurley wined and dined the investigating officers at his home while he was being investigated and had off-the-record discussions about the investigation. Furthermore, despite Recommendation 33 in the RCIADIC Report - that investigating officers into a death in custody not be connected with the police command where the death occurred - the investigating officers had been attached to the Palm Island Police Station for two years $(R v$ Lex Patrick Wotton 2008 at 2-3).

The community response to the death in custody and prejudicial investigation manifested in a public protest. On 26 November 2004 approximately 300 people (one-eighth of the Palm Island population) assembled at the police station demanding the police leave. The group threw stones and mangoes at the police building and yelled abuse at the police. The Queensland Government's response to the protest was to declare a 'state of emergency' on the Island, evacuate medical and teaching staff and send 80 Tactical Response Group Commandos to the Island (Hunter 2005:16).

The police officers were armed and prepared to fire on the protesters to preserve their own life ( $R v$ Wotton 2007 at [6]-[7]). A number of them pointed rifles at the protesters. The officers ultimately retreated to the hospital and police barracks. Over the next three hours, the barracks, police station and court house, 'which were all part of a fairly modest complex of prefabricated buildings', burnt down (Levitt 2008). Some officers sustained minor injuries. There were no serious injuries. The protest entangled 37-year-old Palm Islander man, Lex Wotton, in four years of criminal proceedings that resulted in a criminal sentence of six years imprisonment. He would be condemned for his role in the protest while the police officers would be valorised for their bravery.

\section{Moral Panics}

The protest on Palm Island flooded the national mainstream media. It was portrayed as an impulsive event that was incited by a 'mob' of rioters. In its coverage, the Australian media made no reference to the partial investigation into the death in custody and scant reference to the death in custody itself - the very factors for which the protest was a response. The media did not refer to historic tensions in police-Indigenous relations. Headlines such as 'Trouble in paradise' (Mancuso 2004), 'Palm Island erupts' (Mancuso \& Connolly 2004) and 'Palm Island Explodes: Anarchy on Palm Island on knife's edge overnight' (Lineham \& Seeney 2004) cast the 'riot' as a stain on the otherwise 'idyllic' Palm Island record.

A feature of the Palm Island 'paradise' was the sacrificial police and their embodiment of law and order. Therefore, the 'rioters' were depicted as terrorising innocent police. At the time of the protest the major headlines included, 'Police Riot Terror' (Ketchell et al 2004), 'How rioters set trap for police - Unarmed officers feared they would die as 300 rampaged trap for police' (Ketchell et al 2004a), 'Where the thin blue line walks in fear' (Ketchell 2004), “"They were saying they would kill us" Police tell of terror' (Ketchell 2004a) and 'Police flee after island rampage over jail death' (Anonymous 2004). These depictions would be relied on in prosecution submissions in Wotton's trial and sentencing hearing. The fact that the police officers were armed, pointing their guns at the protesters and ready to fire, was not used as evidence of their agency, but rather as evidence of their fear, which made them take drastic measures (Anonymous 2005). 
The Queensland Police Union (2005:26), Queensland Police Commissioner and the Queensland Government ran a concerted campaign to defend the police officers' role in the riot (Eastley 2004; Pavey 2004). This went hand in hand with the Union's campaign to absolve Hurley of any wrongdoing associated with Mulrunji's death in custody (Willoughby 2007:4). These campaigns featured in newspapers in the days following the protest. Newspapers reported, 'Police lost everything in island riots, says union' (Anonymous 2004a), '[Premier] Beattie defends police tactics in island riot' (Pavey 2004) and 'Queensland Government to meet insurance shortfall' (Anonymous 2004b).

The mainstream media's exposure of the protest resonates with Howard Becker's and Stan Cohen's work on 'outsiders' that reveals how 'it is possible for moral panics over a particular type of deviancy to be created by the sudden dissemination of information about it' (Young 1971:38). Cohen (2004:1) argues that a moral panic occurs when:

A condition, episode, person or group of persons emerges to become defined as a threat to societal values and interests; its nature is presented in a stylized and stereotypical fashion by the mass media; the moral barricades are manned by editors, bishops, politicians and other rightthinking people.

Moral panics can arise from activities that range from being 'quite novel' to 'something which has been in existence long enough, but suddenly appears in the limelight' (Cohen 2004:1). The offence is constructed as sudden and excessive. It is not conveyed as a reasoned response to a legitimate concern. On Palm Island, the protest was not construed as a reaction to the death of Mulrunji or the long history of Indigenous deaths in custody and police aggression towards Indigenous people. Rather, the Palm Islanders were presented as an uncontrollable and irrational group. The spontaneous representation of the protest reinforces its lack of reason. Phil Scraton (2007:25) considered the popular image of the black community's protest against over-policing and deaths in custody in England as a 'riot'. He claimed that it created 'an image of random, chaotic spontaneity' and undermined it as a 'reasoned response' to 'unacceptable differential policing' (Ibid).

Moral panics are directed to a group because of who they are as outsiders. Their outsider status is reinforced through media and political opprobrium. In Wotton's case, the moral panic erupted and was exacerbated because his people were presented as outsiders and threatened those on the inside - the police. The moral panic therefore had the effect of denouncing the Palm Islanders, including devaluing the life of Mulrunji, and vindicating the police's role on Palm Island. The contrast between the morally devoid Palm Islanders and the morally righteous police is a theme that pervaded Wotton's criminal proceedings.

\section{Wotton's Preliminary Criminal Proceedings}

Lex Wotton's crime was his involvement in the protest against the police responsible for the death in police custody of Mulrunji and the mishandling of the ensuing investigation. In 2004 Wotton was charged under s65 of the Criminal Code (Qld) with a maximum penalty of life imprisonment for partaking in a riot in which a building was destroyed. Of the Palm Islanders involved in the protest, Wotton was charged with the most severe offence. ${ }^{2}$ Although his exact involvement was not established in the court proceedings, Wotton was characterised as a leader.

For example, contrast the lesser riot charges under ss61, 63 that were ultimately laid in $R v$ Poynter, Norman \& Parker; ex parte A-G (Qld) 2006; R v Noble 2006. 
This section details the proceedings that Wotton was subjected to before being sentenced in late 2008. It examines the direct impact of the moral panic on Wotton's trial, leading to its relocation from Townsville to Brisbane. This section also considers the ambiguous application of the rule of law to Wotton's case when he was denied bail without sufficient reasons and deprived of open justice in entering his plea.

\section{Relocation of Trial}

The moral panic over the Palm Island protest created by the media, Queensland Government and police led to the relocation of Wotton's trial from Townsville to Brisbane to insulate Wotton from prejudicial publicity. Acting Chief Judge Skoien in Wotton v DPP 2006 (at 3) accepted Wotton's relocation application on the basis that a fair trial could not be guaranteed due to the 'prejudicial pre-trial publicity' surrounding 'the events on Palm Island' that was 'highly adverse to the applicant accused person'. The publicity included 'the remarkable feature of a police officer ... making public statements, which were televised, highly critical of the decision' to grant bail to the accused 'rioters' (at 5-6).

The adverse publicity, according to the judge, induced a 'well-formed' view in the Townsville community that Wotton was criminally responsible (at 5). Wotton's lawyers argued that the publicity amplified the Townsville community's racism towards Palm Islanders. They submitted a survey of residents of the Townsville area from which jurors would be summoned, which revealed that 'the events which gave rise to this prosecution are still well known to virtually 100 per cent of the surveyed people' two years after they occurred (at 4). The judge stated that views about the Palm Island events were not as established in Brisbane (at 5). However, it was unsubstantiated and whether the 'all-white' Brisbane jury that tried Wotton was immune from the moral panic is unknown (Graham 2008).

\section{Wotton's Bail Re-Application for Failure to Give Reasons}

Although Wotton was granted bail immediately after he was charged on 6 December 2004, ${ }^{3}$ it was withdrawn when he entered a guilty plea in April 2007 (the plea did not stand - see the following section). Wotton's application to have his bail reinstated was refused by the Townsville District Court (Wotton v DPP 2007 at 3). The refusal was unsupported by reasons other than the seriousness of the offence and Wotton therefore made a further application to the Supreme Court of Queensland. Wotton's lawyers argued that there was jurisdictional error due to the court's failure to account for the undisputed submission that Wotton was not a 'flight risk', which is crucial to the bail test (at 2).

Helman J of the Queensland Supreme Court dismissed Wotton's application (at 9-10). He was satisfied that the usual process of providing reasons could be bypassed in Wotton's case. Although transparent judicial reasoning is a trademark of the common law system, the judge noted that it was unnecessary in this case to provide reasons unless requested explicitly:

While it is true that in giving his brief reasons his Honour did not state what to any reasonable observer should have been obvious, it is not without significance that he was not asked for any elaboration of his reasons by those representing the applicant (at 10).

Queensland's Chief Magistrate Marshall Irwin granted bail with strict conditions, including a total ban on visiting Palm Island; see Anonymous 2004c. 


\section{Wotton's Application to Withdraw Guilty Plea Given in Closed Court}

Another miscarriage of justice occurred when Wotton sought to enter a plea. A tenet of a fair trial in the common law system is that such pleas are entered in an open court. Wotton was not given this right. A 'closed court' sign was 'illuminated outside the court room' $(R v$ Wotton 2007 at [30]). This meant that his family members, SBS News and others were excluded from this phase of the proceedings. Wotton applied to withdraw the guilty plea because it was given in 'secret'. Brisbane District Court Judge Nase found that the plea was affected by procedural errors (at [14]). The judge stressed the importance of open justice and cited s597C of the Criminal Code that expressly requires that an arraignment and plea take place in an open court (at [25]). The judge withdrew the plea on the basis that a judge cannot allow proceedings to be held in 'secret' (at [29]).

As a result of the withdrawal of Wotton's guilty plea, on 31 May 2007 he was released on bail with strict conditions and ordered to appear at the Brisbane District Court in April 2008 to be tried. On 24 October 2008 the jury convicted Wotton of the offence of rioting with destruction. He was sentenced the following month.

\section{Sentencing Considerations}

On 11 November 2008 Wotton was sentenced for rioting with destruction. This was four years after his offence; after a barrage of media and adverse police union publicity towards Wotton; after judicial remarks on Wotton's culpability and moral wrongness throughout his preliminary proceedings; ${ }^{4}$ and after the acquittal of Hurley for the manslaughter of Mulrunji.

Shanahan J of the Townsville District Court sentenced Wotton to six years imprisonment. In his sentencing remarks he disavowed the context of the death in custody and the mishandled investigation, and focused instead on deterrence and the seriousness of the offence, especially as police officers were victims. A significant sentencing consideration was the vindication of the police who were targeted in the protest. In adopting this approach, the judge referred to the reasoning of the Queensland Court of Appeal, which heard an appeal against the sentences imposed on other protesters who were convicted of lesser rioting charges.

\section{Disavowal of Death in Custody Context and Reinforcement of the Uncivilised}

At the outset, Shanahan J ruled out the death in custody as a matter for consideration in Wotton's sentence. The judge held that the 'riot' was so 'intrinsically dangerous ${ }^{5}$ that circumstances such as Mulrunji's death do not warrant consideration ( $R v$ Lex Patrick Wotton 2008 at 5). He followed the position of the Court of Appeal in reviewing the sentences of other Palm Island 'rioters':

[T] he background to this matter is not particularly relevant for the purpose of the sentence. The reason for that, in my view, is the serious nature of the offence itself, rioting with destruction (at 4).

Shanahan $\mathrm{J}$ characterised the community response to the death in custody as excessive:

Any community can feel badly done by and disagree with what is occurring to them and disagree strongly. They can protest it. What they can't do is take the law into their own hands by

\footnotetext{
See for example, $R v$ Wotton 2007 at [8].

$R v$ Lex Patrick Wotton, 07/11/2008 at 5, citing $R$ v Poynter, Norman \& Parker; ex parte A-G (Qld) [2006] QCA 517 (de Jersey CJ).
} 
descending into lawlessness and rioting. ... Whatever the aggravation, whatever the apparent justification, society cannot accept that that is an appropriate response (at 4).

Shanahan J positioned the offence not in Palm Island's context but in 'recent and not so recent world history' that 'illustrates the immense damage wrought by riots' (at 6, emphasis added). Shanahan J remarked that 'mob conduct' is not 'tolerated in a civilised community' that requires a reasoned response (at 6). His depictions of the uncivilised nature of the rioters appeared through his remarks: 'they descended into lawlessness' (at 3-4) it was 'whole scale violent condemnation' (at 5), and 'the consequence is anarchy' (at 6). In order to prevent such uncivilised acts again, the judge emphasised the role of deterrence in Wotton's sentence. A heavy sentence was needed to 'ensure that [the riot] does not occur again' (at 5).

\section{Seriousness of Offence}

Wotton's sentence was also based on the seriousness of the offence. The judge considered the number of offenders, the damage to public property and the nature of the police victims in assessing its seriousness. First Shanahan J pointed to the fact that 300 people participated in the 'riot'. However, he found that this was only an estimate and 'may well be an exaggeration': 'The video does not disclose that many active participants. There seemed to have been a number who were simply spectators' (at 10). Second, he maintained that the damage occasioned by the riot was of 'a very significant amount': 'Millions of dollars damage was occasioned to the infrastructure of Palm Island and the damage to the community can easily be seen' (at 10). Third, he emphasised that police were 'the target of this riot' when they 'were simply performing their duties as police officers' (at 4).

\section{Vindication and Valorisation of Police Victims}

In sentencing Wotton, Shanahan J sought to vindicate the police. The judge noted: 'It is the [police] identity of the targets of this violent riot which renders the involvement of anyone in it, distinctly grave' (at 5). However, he also recognised that the police sustained 'relatively minor' physical injuries. The most serious injury he referred to was a bruise to an officer's hip (at 9). The judge continued:

What is surprising is that none of [the police] suffered serious injury. That may have been a matter of luck and it may have been your [Wotton's] intention that none of them would be seriously injured, but the simple fact of the matter is that none of them were seriously injured (at 10).

Instead, Shanahan J stressed the emotional toll on the police: 'They were subject to vile abuse, threats of death and taunts for being police officers over a substantial period of time. Many perceived that they were about to die' (at 11). He continued:

It appears that many have suffered emotionally, many have suffered financially and many feel that their careers in the police service have been irrevocably damaged. There has also been much suffering caused to their families, their partners and their children and other families. It should be noted in that regard that one of those officers was in fact Indigenous and he particularly feels put upon by what occurred (at 11).

A manifestation of the police officers' 'horror and terror' was that some of them 'had decided to shoot at the crowd if it came to that' (at 11). Two in particular identified Wotton 'as the person that they would shoot first' (at 11). This police response was not only treated by the judge as justified, but as evidence of Wotton's wrong-doing. The decision to shoot was described as a reasoned response by police officers to an uncivilised act of wrongdoing. Shanahan $\mathrm{J}$ held that a consequence of the riot was that the police officers would no longer feel the same dedication to the Palm Island community. Notwithstanding that many 
officers had 'only recently been sent to Palm Island' (at 4), these officers were put forward as 'dedicated and involved in endeavours to improve relations with Indigenous people' (at 11). They had been 'overcome as a result of what they were subjected to on that day [of the riot]' (at 11).

Finally, the judge diluted the wrongdoing of the police force in the lead-up to the 'riot'. He stated that it was merely the perception of one officer that provoked an unwarranted response:

To add the obvious, that one police officer is perceived, whether or not with justification to have done a terribly bad thing, does not justify the wholesale, violent, condemnation of the contingent of which he forms part (at 5).

\section{Wotton's Leadership}

Shanahan J regarded Wotton as a 'major player' and 'leader' in the riot. He is conceived as encouraging the worst and most unruly aspects of the Palm Island community. The judge points to evidence that Wotton gave a speech at the public meeting that indicated that things were going to burn' (at 6). But despite the attempt to put Wotton forward as an instigator of the 'riot', the more significant evidence in the sentencing highlighted Wotton's good character. The judge described Wotton's attempts to assist the police escape and 'lessen the chances of the police officers being injured' (at 8). He referred to Wotton's role in organising transport to move the police off the island and to redirect the crowd:

$[\mathrm{O}] \mathrm{n}$ two occasions you took the crowd away from besieging the police. This allowed the police to leave the police station to go to the barracks and later from the barracks to go to the hospital. ... I am of the view that you personally moved the crowd away on each of those occasions. I am also of the view that you negotiated in an endeavour to move the police off the island ... aimed at lessening the prospect of the police being seriously injured (at 8-9).

Shanahan J concluded his remarks by referring to Wotton's contribution to the Palm Island community. He noted that despite some alcohol-related offences in his youth, Wotton 'overcame those problems and has endeavoured to assist others of your community to overcome them' (at 13). Wotton had been involved in the Palm Island Men's Group and with an alcohol and drug rehabilitation program to assist youth in relation to suicide problems in the community (at 13).

Evidence of Wotton's good character was not used to assess his purpose for protesting after Mulrunji's death in custody. Therefore, it only reduced mildly the head sentence which was primarily decided with reference to deterrence and the seriousness of the offence. Nonetheless, the mitigating factors of 'trying to minimise the chances of serious injury done to the police', as well as the adverse impact of imprisonment and the glowing references from community members and prominent people across Australia, reduced the head sentence from seven years to six years, with a two-year non-parole period (at 14). The earliest date for Wotton's release from prison is 18 July 2010.

\section{Concluding Remarks}

Andrew Boe (2008), who acted for Palm Island in the coronial inquiry into Mulrunji's death, argues that it is 'terribly naïve' to conceive Wotton's offence within the framework of deterrence because it undermines the death in custody as the catalyst for the protest:

[A]s a justice system, we didn't have the maturity to examine the context ... If you look at the ledger sheet on the whiteboard of what has been the justice outcomes from this death in custody, you will see in some detail the successes for the police side of events; you'll see no true liability being attached, yet on the other side of the ledger, you've had many, many men charged 
wrongly and acquitted or not proceeded with of the riot, yet they were banished away from their homelands for three months. You've had many people incarcerated, because once charged with riot, their history meant that they didn't get bail. You've had many women traumatised by guns being pointed to their heads when the riot police arrive shortly after the riot. You've had the acquittal of Hurley and now you have some men, having gone to jail for being involved in the response to this death.

The ledger sheet continued to favour the police in the months following Wotton's conviction. The 22 police officers on Palm Island at the time of the protest were honoured with bravery awards and were paid generous compensation sums (Anonymous 2008), and Hurley was granted the right to reopen the coronial inquiry to clear his name. ${ }^{6}$ An officer and close friend of Hurley who investigated Hurley's role in the death in custody, Detective Sergeant Robinson, was awarded the top police bravery medal for 'acts of exceptional bravery in hazardous circumstances' (Michael 2008).

The bravery awards were the climax of the narrative that portrayed the police on Palm Island as morally righteous. The courts', media's and State Government's valorisation of the police were key parts of this narrative. The courts that sentenced the 'rioters' emphasised the sacrifices of the police officers who were sent to quell the 'riot'. The Queensland Police Minister, Judy Spence (2008), claimed the police officers on Palm Island 'really exercised enormous restraint and commonsense and sound judgment [sic] in dealing with that riot'.

I think it was extraordinary that given their frame of mine [sic] and fear at the time, that none of them chose to use their weapons, which they had at their disposal. ... I think our police do a marvellous job on a daily basis ... I mean it's a tough situation and we're asking our police to do this job on our behalf, and I think people lose sight of the fact that they are there every day, and for the most part they're doing a great job (Ibid).

By contrast, Lex Wotton and those involved in the Palm Island protest were characterised as blameworthy because of their uncivilised ways. The moral indignation and panic in relation to the protests allowed the Palm Island group to be cast as deviant. Their deviance exculpated the police officers and overshadowed the central Palm Island issue of the death in custody and the subsequent police cover-up. It erased the story that almost 20 years after the Royal Commission into Aboriginal Deaths in Custody the police continue to arrest Indigenous people for minor offences, that innocent Indigenous people continue to die in police custody, and that there is a failure to properly investigate these deaths and hold those responsible to account.

Thalia Anthony

Lecturer, Sydney University Law School

\section{Cases}

$R \quad v$ Lex Patrick Wotton 2008 Townsville District Court, 07/11/2008, Unreported, $<$ http://archive.sclqld.org.au/qjudgment/sentencing/2008/RvWotton.pdf $>$ accessed 25 March 2009

6 In December 2008, Hurley was given the right to re-open the Clements Coronial Inquiry, which found him responsible for Mulrunji's death in custody. Judge Bob Pack of the Townsville District Court allowed Hurley's challenge on the basis that Clements' findings were supported by witnesses' 'erroneous recollections'. This has been heavily criticised by Indigenous people. See Murphy 2008. The decision is being appealed to the Queensland Court of Appeal. The appeal is to be heard on 25 May 2009. 
$R v$ Noble [2006] QDC 011

$R$ v Poynter, Norman \& Parker; ex parte A-G (Qld) [2006] QCA 517

$R v$ Wotton [2007] QDC 181

Wotton v DPP [2006] QDC 202

Wotton v DPP [2007] QSC 42

\section{References}

ABS (Australian Bureau of Statistics) 2007 1301.0 - Year Book Australia No. 89, $<$ http://www.ausstats.abs.gov.au/ausstats/subscriber.nsf/0/D6C6B02D31617DA4CA257 26D000467A6/\$File/13010_2007.pdf> accessed 27 March 2009

Anonymous 2004 'Police flee after island rampage over jail death' Hobart Mercury 27 November

Anonymous 2004a 'Police lost everything in island riots, says union' Australian Associated Press 29 November

Anonymous 2004b 'Queensland Government to meet insurance shortfall' Australian Associated Press 29 November

Anonymous 2004c 'Palm rioters given bail' The Age 6 December

Anonymous 2005 'Police "prepared to shoot" during Palm Island riots' Sydney Morning Herald 13 April 2005

Anonymous 2008 'Compo deal for Palm Island police officer' ABC News 28 May

Boe A 2008 on 'The Sentencing of Lex Wotton' The Law Report <www.abc.net.au/rn/lawreport/stories/2008/2416076.htm> accessed 25 March 2009

Cohen S 2004 Folk Devils and Moral Panics (3rd edn) Routledge London

Eastley T 2004 'Qld police commissioner defends Palm Island response' Australian Broadcasting Corporation 30 November

Graham C 2008 'Lex Wotton Trial: Jury returns GUILTY verdict' National Indigenous Times 25 October

Hunter C 2005 'Palm Island: the truth behind the media portrayal - an interview with Erykah Kyle, Chairperson of the Palm Island Aboriginal Council' Indigenous Law Bulletin vol 6 no 12 p 16

Ketchell M 2004 'Where the thin blue line walks in fear' The Sunday Mail 28 November

Ketchell M 2004a “"They were saying they would kill us” Police tell of terror' The Sunday Mail 28 November

Ketchell M, Webster D \& Dibben K 2004a 'How rioters set trap for police - Unarmed officers feared they would die as 300 rampaged trap for police' The Sunday Mail 28 November

Ketchell M, Webster, D \& Dibben K 2004 'Police riot terror' Herald Sun 28 November 
Levitt S (Wotton's lawyer) 2008 on 'The Sentencing of Lex Wotton' The Law Report <www.abc.net.au/rn/lawreport/stories/2008/2416076.htm> accessed 25 March 2009.

Lineham S \& Seeney H 2004 'Palm Island Explodes: Anarchy on Palm Island on knife's edge overnight' Townsville Bulletin 27 November

Mancuso R \& Connolly S 2004 'Palm Island erupts: buildings burn, police threatened' Australian Associated Press 26 November

Mancuso R 2004 'Palm Island: trouble in paradise' Australian Associated Press 26 November

Michael P 2008 'Darren Robinson faces discipline over Mulrunji death-in-custody' The Australian 4 November

Murphy P 2008 'Aboriginal leaders slam decision to re-open Palm Island inquest' The Australian 18 December

Pavey A 2004 'Beattie defends police tactics in island riot' Australian Associated Press 29 November

Queensland Police Union 2005 Police Journal July

RCIADIC (Royal Commission Into Aboriginal Deaths In Custody) 1991 National Report

Scraton P 2007 Power, Conflict and Criminalisation Routledge London

Spence J 2008 on 'The Sentencing of Lex Wotton' The Law Report <www.abc.net.au/rn/lawreport/stories/2008/2416076.htm> accessed 25 March 2009

Willoughby S 2007 'Solidarity for Hurley: Incensed Coast cops in protest' Gold Coast Bulletin 31 January

Wootten H 1991 'Report of the inquiry into the death of David John Gundy' Royal Commission Into Aboriginal Deaths In Custody

Young J 1971 'The role of Police as Amplifiers of Deviancy, Negotiators of Reality and Translators of Fantasy' in Cohen S (ed) Images of Deviance Penguin Harmondsworth 